\title{
Tricuspid valve dysplasia in a domestic feline: case report
}

\section{Displasia valvar tricúspide em um felino doméstico: relato de caso}

\author{
Matheus Matioli Mantovani ${ }^{1 *}$; André Martins Gimenes ${ }^{1}$; \\ Jacqueline Ribeiro de Castro'; Guilherme Teixeira Goldfeder'; \\ Maria Helena Matiko Akao Larsson ${ }^{3}$; Denise Saretta Schwartz ${ }^{3}$
}

\begin{abstract}
Tricuspid valve dysplasia (TVD) is a congenital heart defect described in dogs and cats; however, in Brazil there are no reports of this condition in cats. Therefore, our goal was to report a case of TVD in a domestic cat. A four-year-old, female, domestic short hair cat that was seen at the Cardiology Service of the Veterinary Teaching Hospital, University of São Paulo, for apathy, appetite loss and dyspnea for five days. During physical examination, dyspnea with a restrictive respiratory pattern due to pleural effusion was observed. Thoracocentesis was performed and $450 \mathrm{~mL}$ of serosanguineous fluid was drained. Two-dimensional echocardiography in the right parasternal short-axis plane at the level of the papillary muscles showed right ventricular dilatation and paradoxical septal motion. On the left parasternal apical four-chamber view, significant dilatation of the right chambers, loss of mobility of the septal leaflet of the tricuspid valve and a thickened mural leaflet chordae with anomalous insertion were observed. Based on clinical and echocardiographic aspects, a diagnosis of TVD was given. Treatment was initiated with enalapril $0.5 \mathrm{mg} / \mathrm{kg}$, furosemide $0.5 \mathrm{mg} / \mathrm{kg}$ and pimobendan $0.3 \mathrm{mg} / \mathrm{kg}$ every 12 hours, all per os. The patient experienced remission of clinical manifestations and survived for 50 days after diagnosis.
\end{abstract}

Key words: Congenital heart disease. Echocardiography. Cat. Valvopathies.

\section{Resumo}

Displasia valvar tricúspide (DVT) é um defeito cardíaco congênito descrito em cães e gatos. Entretanto no Brasil ainda não há relato desta cardiopatia em felinos. Desta forma, objetivou-se relatar um caso de DVT em um felino doméstico. Uma gata de pelo curto, com quatro anos de idade foi atendida no Serviço de Cardiologia do Hospital Veterinário da Universidade de São Paulo, apresentando apatia, perda de apetite e dispneia há cinco dias. Durante o exame físico observou-se dispneia com padrão respiratório restritivo devido a presença de efusão pleural. Foram drenados $450 \mathrm{~mL}$ de líquido serosanguinolento por meio de toracocentese. $\mathrm{O}$ ecocardiograma no modo bidimensional, pela janela paraesternal direita, ao eixo curto transversal ao nível dos músculos papilares, revelou hipertrofia excêntrica do ventrículo direito e movimento septal paradoxal. Pela vista apical quatro câmaras, na janela paraesternal esquerda, observou-se importante remodelamento de câmaras cardíacas direitas. A valva tricúspide apresentou-se com perda de mobilidade de sua cúspide septal e espessamento de cordoalha tendínea da cúspide mural, com inserção anômala. Com base nos aspectos clínicos e ecocardiográficos, instituiu-se o dianóstico de DVT. Iniciou-se o tratamento com enalapril $(0,5 \mathrm{mg} / \mathrm{kg})$, furosemida $(0,5 \mathrm{mg} / \mathrm{kg})$ e pimobendan

\footnotetext{
${ }^{1}$ Pós-graduandos, Faculdade de Medicina Veterinária e Zootecnia, USP, São Paulo, SP, Brasil. E-mail: matheus2mvet@gmail. com; andre_gimenes@hotmail.com; jack_ufu@yahoo.com.br

2 Médico Veterinário, USP, São Paulo, SP, Brasil. E-mail: guigagold@hotmail.com

3 Profs, USP, São Paulo, SP, Brasil. E-mail: akaolar@usp.br; dschwartz@usp.br

* Author for correspondence
} 
$(0,3 \mathrm{mg} / \mathrm{kg})$, pela via oral a cada 12 horas. O paciente apresentou remissão das manifestações clínicas, sobrevivendo por 50 dias após o diagnóstico.

Palavras-chave: Cardiopatia congênita. Ecocardiografia. Gato. Valvopatias.

\section{Introduction}

Tricuspid valve dysplasia (TVD) is a congenital malformation that may affect the valve leaflets, chordae tendineae and/or papillary muscles, resulting in primary tricuspid valve insufficiency (OYAMA, 2009). Chronically, tricuspid valve insufficiency leads to volume overload of the right heart chambers and subsequent dilatation, elevated right atrial (RA) pressure and the development of right sided congestive heart failure (RCHF) (MACDONALD, 2006).

The etiology of TVD is uncertain, however, a familial heritage is proposed in some dog breeds, such as the Labrador retriever and dogue de Bordeaux (ANDELFINGER et al., 2003). In cats, although there is no conclusive evidence that TVD is familial, a retrospective study (CHETBOUL et al., 2004) found that malformation of the tricuspid valve occurred more frequently in the Chartreux and European shorthair breeds.

Diagnosis of TVD is based on clinical examination findings in addition to other auxiliary tests. Clinically, patients with TVD may have distended jugular veins, a positive jugular pulse, ascites, hepatomegaly and dyspnea secondary to pleural effusion, all due to RCHF (OYAMA, 2009). Echocardiographic evaluation shows a significant enlargement of the right atrium and ventricle, and thickened and hypokinetic tricuspid leaflets, which may be attached to the interventricular septum or to the papillary muscles (BOON, 2011). Occasionally, the septal and mural tricuspid valve leaflets may be displaced downwards, featuring the Ebstein anomaly (ANDELFINGER et al., 2003).

Tricuspid valve Displasia has been described in dogs (OLIVEIRA et al., 2011) and cats (CHETBOUL et al., 2004; RIESEN et al., 2007).
However, there are no reports of this disease in cats in Brazil. Therefore, this study aimed to report a case of TVD in a domestic cat in Brazil.

\section{Case Report}

A four-year-old, female, domestic shorthair cat, $2.8 \mathrm{~kg}$ of body weight, was brought to the Cardiology Service of University of Sao Paulo Teaching Hospital for lethargy, decreased appetite and dyspnea for the last five days.

On physical examination, the cat had pale mucous membranes, an increased capillary refill time, a restrictive pattern of inspiratory dyspnea and mild dehydration. Heart rate (HR) was $200 \mathrm{bpm}$ and respiratory rate was $62 \mathrm{rpm}$. On cardiopulmonary auscultation, there were decreased breath sounds, a regular heart rhythm and muffled heart sounds without evidence of a murmur.

Systolic arterial blood pressure was $110 \mathrm{mmHg}$, determined by the noninvasive Doppler method. The patient was directed to intensive care, and oxygen was initiated with a face mask $(2 \mathrm{~L} / \mathrm{min})$. After stabilization, the cat was submitted to thoracic ultrasound. A significant amount of anechoic content was visualized in both hemithoraces, and $450 \mathrm{~mL}$ of a serosanguineous fluid was drained by thoracocentesis.

Based on the congestive symptoms, two doses of furosemide were administered subcutaneously with an interval of $3 \mathrm{~h}$ between doses $(2 \mathrm{mg} / \mathrm{kg}$ and $1 \mathrm{mg} / \mathrm{kg}$, respectively). After these procedures, the cat had a general improvement, with respiratory pattern normalization. Blood work analyses were then performed which included a biochemical profile (urea creatinine, ALT, AST, GGT, alkaline phosphatase, total protein, albumin, sodium and 
potassium) and hemogram (CBC) including a platelet count. A mild normocytic normochromic anemia was observed on the CBC (PCV: 24\%; MCV: $44 \mathrm{fL}$; CHCM: 30\%). All other results were within normal feline reference ranges.

An echocardiogram was performed, including $\mathrm{M}$ and 2D modes, in addition to Doppler (pulsed, continuous and color-flow) (GE® Vivid 7), based on Boon (2011).

On the apical four-chamber view, the right chambers were significantly dilated. The septal leaflet of the tricuspid valve had a normal appearance, but a loss of mobility secondary to shortening of the chordae tendineae. The chordae corresponding to the mural cusp was thickened ( 0.25 $\mathrm{cm}$ ) and had an anomalous insertion to the middle third of the cusp (Figure 1A). Color-flow Doppler showed turbulent systolic flow within the RA due to significant tricuspid valve regurgitation (Figure 1B). There was a visible enlargement of the right ventricle (RV) and paradoxical septal motion on the right parasternal short axis view at the papillary muscle level, assessed by 2D mode (Figure 1C). Tricuspid annular plane systolic excursion (TAPSE) was $2.56 \mathrm{~mm}$ (Figure 1D).

Figure 1. A- Echocardiographic image from the left apical parasternal four chamber view, showing significant RA and RV dilation and thickened mural tricuspid cordae tendineae (arrow). B- Doppler image with color flow mapping demonstrating turbulent systolic flow within the right atrium. C- 2-D mode image of the left ventricle, obtained from the right transversal parasternal view. D- Measurement of Tricuspid Annular Plane Systolic Excursion (TAPSE), obtained in M-mode, transversal left apical four chamber caudal parasternal view. (RA: right atrium; RV: right ventricle; LA: left atrium; LV: left ventricle).
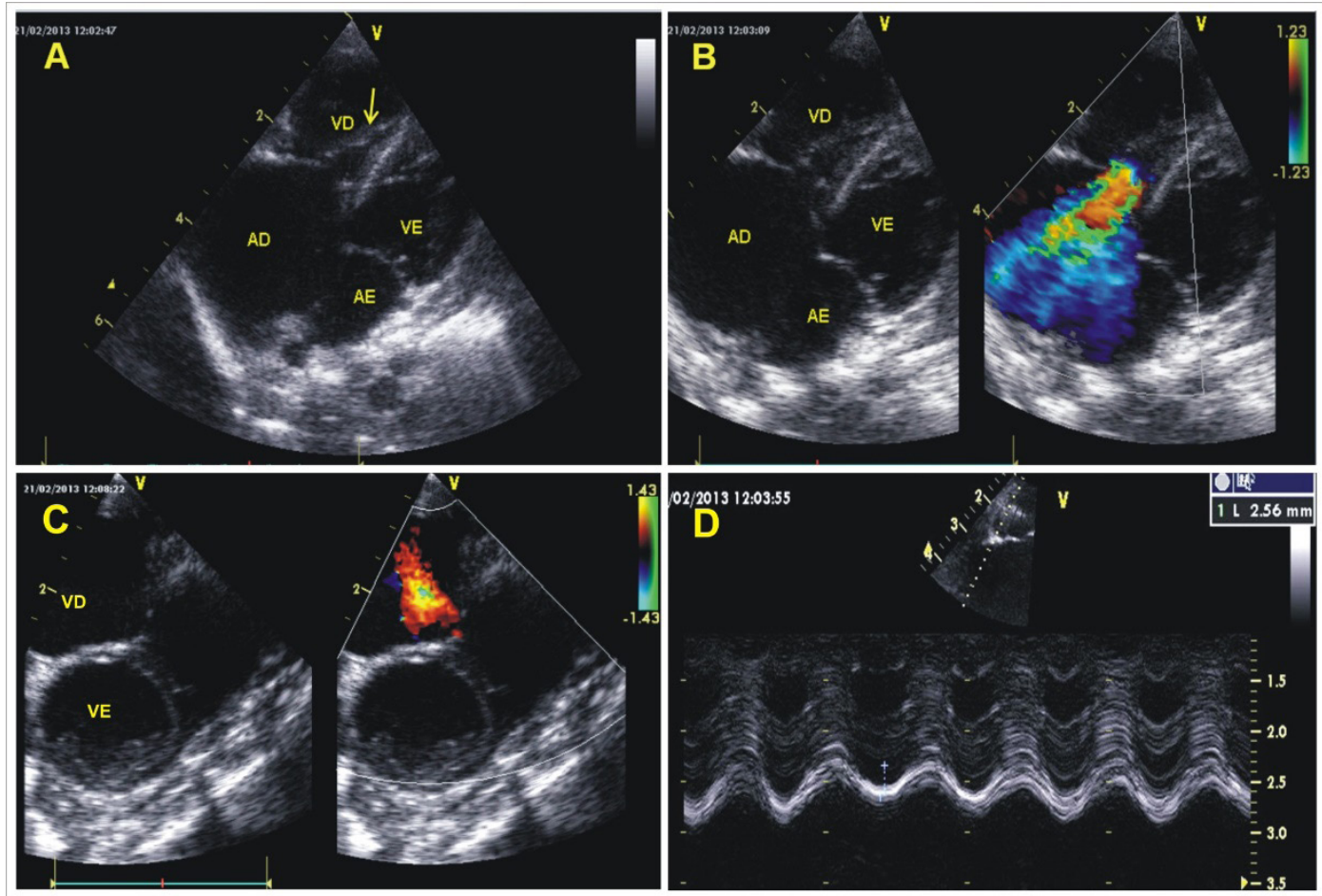

Source: Cardiology Service, Department of Internal Medicine, FMVZ, USP. 
Maximum velocity of tricuspid regurgitation was $2.90 \mathrm{~m} / \mathrm{s}$ with a $33.77 \mathrm{mmHg}$ gradient. The major remodeling of the right heart chambers, and the presence of pleural effusion without vena cava collapse during inspiration, confirmed RCHF.

Left ventricular systolic function (LV) was within the reference values for the species (Table
1). The assessment of diastolic function was compromised by the fusion of $\mathrm{E}$ and $\mathrm{A}$ waves of mitral flow, due to the short period of diastolic filling secondary to the high HR (219 bpm), which was not responsive to a vagal maneuver. The microbubbles test with saline was negative for pathologic intracardiac shunts.

Table 1. Echocardiographic parameters obtained from a female cat with tricuspid valve dysplasia.

\begin{tabular}{ccc}
\hline Variable & Values & Reference values* \\
\hline IVSd $(\mathrm{cm})$ & 0.34 & $0.30-0.60$ \\
IVSs (cm) & 0.42 & $0.40-0.90$ \\
LVWd (cm) & 0.34 & $0.25-0.60$ \\
LVWs (cm) & 0.44 & $0.43-0.98$ \\
LVIDd (cm) & 1.65 & $1.12-2.18$ \\
LVIDs (cm) & 1.08 & $0.64-1.68$ \\
EF $(\%)$ & 57 & $55-85$ \\
FS (\%) & 34 & $30-50$ \\
LA/Ao & 1.61 & $0.88-1.79$ \\
Pulmonary arterial flow (m/s) & 0.81 & $0.50-1.60$ \\
Aortic flow (m/s) & 0.83 & $0.80-1.90$ \\
Transmitral flow $(\mathrm{m} / \mathrm{s})$ & 0.82 & - \\
\hline
\end{tabular}

*Reference values (BOON, 2011). IVSd: interventricular septum in diastole; IVSs: interventricular septum in systole; LVWd: left ventricular wall in diastole; LVWs: left ventricular wall in systole; LVIDd: left ventricular internal diameter in diastole; LVIDs: left ventricular internal diameter in systole; EF: ejection fraction (Simpson method); FS: fractional shortening; LA/AO: left atrium/ aorta ratio.

Based on clinical and echocardiographic characteristics, a diagnosis of TVD associated with RCHF was made.

The prescribed treatment was enalapril $0.5 \mathrm{mg} /$ $\mathrm{kg}$, furosemide $0.5 \mathrm{mg} / \mathrm{kg} / \mathrm{PO}$ and pimobendan $0.3 \mathrm{mg} / \mathrm{kg}$ orally, administered every $12 \mathrm{~h}$. During the follow-up period, the cat had four rechecks all of which confirmed remission of clinical manifestations. The cat survived for 50 days after the diagnosis, with subsequent death at home.

\section{Discussion}

This is the first report of TVD in a domestic cat in Brazil. Diagnostic confirmation was performed using Doppler echocardiography and malformations of the tricuspid valve apparatus were observed as described in the literature (CHETBOUL et al., 2004; BOON, 2011).

A retrospective study in cats with heart disease over a period of eight years (RIESEN et al., 2007) determined a prevalence of $11.8 \%$ (48/408) of congenital heart defects. Ventricular septal defect was the most frequent anomaly $(56.3 \%)$, followed by mitral valve dysplasia (14.6\%) and TVD $(10.4 \%)$. Although congenital heart disease in cats seems to be more frequent in males, and the incidence of mitral valve dysplasia is reported most frequently (RIESEN et al., 2007), here we report a case of TVD in a female domestic cat. 
Cardiovascular malformations are important causes of morbidity and mortality in dogs and cats less than one year old (OLIVEIRA et al., 2011). However, cats with congenital defects are usually diagnosed as adults (MACDONALD, 2006). In this report, the patient presented with clinical manifestations of CHF resulting from TVD at four years old.

Tricuspid valve dysplasia is characterized by valvular regurgitation, a progressive increase in end diastolic pressure in the RA and RV resulting in dilatation of these heart chambers, systemic venous hypertension and development of RCHF (OYAMA, 2009). Dyspnea resulting from pleural effusion, as observed in this case, is a characteristic finding of RCHF caused by TVD.

The increase in the gradient pressure between RA and RV, estimated by the regurgitant tricuspid flow, the absence of a collapsed vena cava and the paradoxical movement of the interventricular septum can be explained by the progressive increase in the filling pressures of the right heart chambers (MACDONALD, 2006; OYAMA, 2009).

Tricuspid annular plane systolic excursion is an echocardiographic index used to evaluate the RV systolic function, which is measured by apical displacement of the lateral portion of the tricuspid valve annulus during systole, in the M-mode (PARIAUT et al., 2012). The measured value of TAPSE was $2.56 \mathrm{~mm}$, which is below the value reported in the literature for Maine Coon cats (8.70 to $10.70 \mathrm{~mm}$ ) (ITIKAWA et al., 2012). Although this was a domestic shorthair cat, the low TAPSE values measured in this patient suggest systolic dysfunction of the RV due to volume overload resulting from TVD (GORDON et al., 2012).

Although the presence of a holosystolic murmur in the right hemithorax was expected (MACDONALD, 2006), it was not present in this case. The absence could be explained if the pressures in the RA and RV were equalized because of RV failure. However, this does not apply to this case since a $33.77 \mathrm{mmHg}$ pressure gradient was detected between the right heart chambers. Auscultation of heart sounds was probably impaired by the presence of fluid in the pleural space.

The echocardiographic variables used for evaluation of LV systolic function were ejection fraction and shortening fraction, which were both in the reference range for feline species (Table 1) (BOON, 2011). However, these parameters could be overestimated due to the paradoxical movement of the interventricular septum and may not properly represent the LV systolic function (CHETBOUL et al., 2015).

Evaluation of diastolic function was not possible due to the patient's tachycardia which was caused by increased sympathetic tone, secondary to stress. Heart rates above 170-180 bpm in felines promote fusion of transmitral flow waves, affecting this assessment (BOON, 2011).

Despite the fact that TVD may be associated with a patent foramen ovale (CHETBOUL et al., 2004), this association was not present in this case as confirmed by the negative result of the microbubble test.

The normocytic normochromic anemia could be related to CHF due to an associated inflammatory process (KLUTSTEIN; TZIVONI, 2005). However, the cause of the anemia was not investigated due to the owner's financial restrictions.

Although there is restricted literature regarding the use of pimobendan in cats, it can be justified by the presence of RV systolic dysfunction and the presence of significant volume overload due to TVD (GORDON et al., 2012). Therefore, pimobendan was prescribed because the patient had signs of RCHF.

Necropsy was not performed because death occurred at home and the cat was not brought back to the hospital. Nevertheless, some information was collected through telephone contact in which the owner reported that the patient was stable, but 
after intense exercise she developed acute dyspnea and died. The absence of a necropsy to confirm TVD does not invalidate the diagnosis because echocardiographic examinations are accurate in identifying congenital heart defects (CHETBOUL et al., 2004).

\section{Conclusion}

This is first case report of TVD in a domestic cat in Brazil, diagnosed on echocardiographic exam.

\section{Acknowledgements}

The authors thank all of the staff from the Veterinary Teaching Hospital at the School of Veterinary Medicine (FMVZ), University of São Paulo (USP) and for the institutional support from the Department of Internal Medicine, FMVZUSP, as well as São Paulo Research Foundation (FAPESP) and Coordination for the Improvement of Higher Education Personnel (CAPES) for the scholarships given to some of the authors.

\section{References}

ANDELFINGER, G.; WRIGHT, K. N.; LEE, H. S.; BENSON, D. Canine tricuspid valve malformation, a model of human Ebstein anomaly, maps to dog chromosome 9. Journal of Medical Genetics, London, v. 40, n. 5, p. 320-324, 2003.

BOON, J. A. Congenital shunts and AV valve dysplasia. In: Veterinary echocardiography. $2^{\text {th }}$ ed. New Jersey: Willey-Blackwell, 2011. p. 337-360.

CHETBOUL, V.; BUSSADORI, C.; MADRON, E. Global left ventricular systolic function assessment. In: Clinical echocardiography of the dog and cat.

Waltham: Elsevier, 2015. p. 111-125.
CHETBOUL, V.; TRAN, D.; CARLOS, C.; TESSIER, D.; POUCHELON, J.L. Congenital malformations of the tricuspid valve in domestic carnivores: a retrospective study of 50 cases. Schweiz Arch Tierheilkd, Zurich, v. 146, n. 6, p. 265-275, 2004.

GORDON, S. G.; SAUNDERS, A. B.; ROLAND, R. M.; WINTER, R.L.; DROURR, L.; ACHEN,S.E.; HARIU, C.D.; FRIES, R.C.; BOGGESS, M.M.; MILLER, M.W. Effect of oral administration of pimobendan in cats with heart failure. Journal of the American Veterinary Medical Association, Schaumburg, v. 241, n. 1, p. 89-94, 2012.

ITIKAWA, P. H.; GOLDFEDER, G. T.; OLIVEIRA, V. M. LARSSON, M.H.M.A. Tricuspid Annular Plane Systolic Excursion (TAPSE) measurements in maine coon cats. Journal of Veterinary Internal Medicine, Lawrence, v. 26, n. 3, p. 724, 2012.

KLUTSTEIN, M. W.; TZIVONI, D. Anaemia and heart failure: aetiology and treatment. Nephrology Dialysis Transplantation, Oxford, v. 20, n. 7, p. 7-10, 2005.

MACDONALD, K. A. Congenital heart diseases of puppies and kittens. Veterinary Clinics of North America: Small Animal Practice, Oxford, v. 36, n. 3, p. 503-531, 2006.

OLIVEIRA, P.; DOMENECH, O.; SILVA, S.; VANNINI, S.; BUSSADORI, R.; BUSSADORI, C. Retrospective review of congenital heart disease in 976 dogs. Journal of Veterinary Internal Medicine, Lawrence, v. 25, n. 3, p. 477-483, 2011.

OYAMA, M. A. Neurohormonal activation in canine degenerative mitral valve disease: implications on pathophysiology and treatment. Journal of Small Animal Practice, Oxford, v. 50, n. 1, p. 3-11, 2009.

PARIAUT, R.; SAELINGER, C.; STRICKLAND, H.; BEAUFRERE, H.; REYNOLDS, C. A.; VILA, J. Tricuspid annular plane systolic excursion (TAPSE) in dogs: reference values and impact of pulmonary hypertension. Journal of Veterinary Internal Medicine, Lawrence, v. 26, n. 5, p. 1148-1154, 2012.

RIESEN, S. C.; KOVACEVIC, A.; LOMBARD, C. W.; ANBERGER, C. Prevalence of heart disease in symptomatic cats: an overview from 1998 to 2005. Schweiz Arch Tierheilkd, Zurich, v. 149, n. 2, p. 65-71, 2007. 